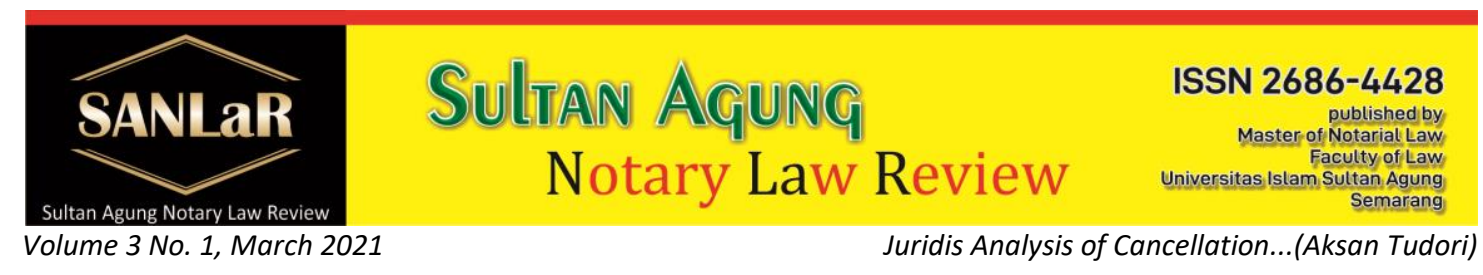

\title{
Juridis Analysis of Cancellation of Sale \& Purchase Agreement by Heirs in Matter of Buyer/Seller Who Has Died
}

\author{
Aksan Tudoni ${ }^{*}$, Akhmad Khisni ${ }^{* *}$ and Amin Purnawan ${ }^{* * *}$ ) \\ *) Student of Master of Notary Law, Faculty of Law, Universitas Islam Sultan Agung \\ (UNISSULA) Semarang \\ E-mail: aksantudoni1982@gmail.com \\ $\left.{ }^{* *}\right)$ Lecturer of Master of Notary Law, Faculty of Law, Universitas Islam Sultan Agung \\ (UNISSULA) Semarang \\ $\left.{ }^{* * *}\right)$ Lecturer of Master of Notary Law, Faculty of Law, Universitas Islam Sultan Agung \\ (UNISSULA) Semarang
}

\begin{abstract}
PPJB land contains the rights and obligations of the parties who made it, so that if the matters that have been agreed in the deed of sale and purchase are violated or not fulfilled by the parties who made it then the parties are authorized to request cancellation in the agreement before the court. In practice, the sale and purchase agreement can be revoked by the heirs. The purpose of this study; to find out how the position of the Heirs' Law and legal protection to the Buyer in the case of the Sale and Purchase Agreement entered into by the Heir is canceled by the heirs and How the Laws of the Cancellation of the Sale and Purchase Agreement are Unilateral by the Heirs. The method used in this study is the Sociological Juridical method, the specification in this study is descriptive analytical, the data used is primary and secondary data, using data collection with interviews and library studies, qualitative data analysis, problems analyzed with theory, legal certainty and Authority Theory. The results of this study show that, the heirs can cancel the sale and purchase of the heirs' land if the legal conditions of the sale and purchase are not met through the court. Heirs who do not give their consent in the sale and purchase of inherited land as their right, have the right to cancel the sale and purchase of the land. If an agreement does not meet the Subjective requirements, then the agreement can be revoked. The PPJB Deed made by the Notary is basically an authentic act that will not be disputed if one party does not feel harmed, but with the content of the agreement in PPJB then the cancellation can arise a problem because one party feels harmed by the other party. The seller who is the heir has an obligation to continue the agreement, because the heirs receive the obligation from the heirs in general, in the sense of assets and passions of the heirs are the responsibility of the heirs.
\end{abstract}

Keywords: Sale and Purchase Agreement; Heirs; Cancellation of Sale and Purchase. 


\section{Introduction}

Bonding Sale and Purchase (PJB) of land between the parties can be done through an act under hand or can also be done through an act made in the presence of a Notary. For lands with a Certificate of Ownership (SHM) as well as land that does not have a Certificate of Ownership (SHM) a bond of sale can be made in the presence of a Notary. The bond of sale and purchase of land with the status of Certificate of Ownership is an initial legal act that precedes the legal act of sale of land. So the bond of sale and purchase is different from the legal act of buying and selling land. The notary has the authority to make a deed of sale and purchase of land with the status of Certificate of Title (SHM) but is not authorized to make an authentic deed of sale and purchase of land with certificate of title (AJB). ${ }^{1}$

In principle a Land Purchase Agreement (PJB) is subject to the general provisions of the agreement contained in Book III of the Civil Law Law (KUHPerdata) on the Alliance Article 1313 KUHPerdata provides a summary of the Agreement is "an agreement is an act with which one person or more ties himself to one or more people ". The subject gives the definition of agreement is "An event in which one person promises to another or where the two people promise each other to do something. ${ }^{2}$ Article 1338 paragraph (1) of the Civil Code states that, all agreements made legally apply as law to those who make them. Article 1338 contains the principle of freedom of contract, meaning that every person is free to enter into an agreement of any kind, regardless of form, content, name and to whom the agreement is addressed. From this principle it can be concluded that society is allowed to make agreements in the form and content of anything (about anything) and that agreement binds those who make it like a law.

However, in the practice before the sale and purchase of land in front of the authorized PPAT, the parties made an act of binding the sale and purchase of land in front of the Notary. The binding is intended as a preliminary agreement of the main purpose of the parties to make the transfer of rights to the land. This sale and purchase agreement contains promises to do land sales when the requirements required for it have been met. ${ }^{3}$ The deed of sale and purchase of land in practice is often made in the form of an authentic act made in the presence of a Notary, so that the Deed of Sale and Purchase Act is an authentic act that has perfect proof of power.

This is intended by the parties to provide greater protection and legal certainty to the parties who created it. Because the Notary in making the act is not biased and protects the interests of the parties objectively. With the help of a Notary, the parties who make the sale and purchase agreement will get help in formulating the things that will be promised. But an agreement can not always work in accordance with the agreement desired by the parties. Under certain conditions can be found the

\footnotetext{
${ }^{1}$ Muchlis Patahna, Notary Problematics, Rajawali, Jakarta, 2009) p. 9.

2 Subject, Law of Agreement, Intermasa, Jakarta, 1996 p. 1.

${ }^{3}$ Supriadi, Ethics and Responsibilities of the Legal Profession in Indonesia, Sinar Grafika, Jakarta, 2006) p. 12
} 
occurrence of various things, which result in an agreement cancellation, either canceled by the parties or by court order. ${ }^{4}$

Bonding Sale and Purchase (PJB) of land between the parties can be done through an act under hand or can also be done through an act made in front of notaries. For lands with a Certificate of Ownership (SHM) as well as land that does not have a Certificate of Ownership (SHM) a bond of sale can be made in the presence of a Notary. The bond of sale and purchase of land with the status of Certificate of Ownership is an initial legal act that precedes the legal act of sale of land. So the bond of sale and purchase is different from the legal act of buying and selling land. The notary has the authority to make a deed of sale and purchase of land with the status of Certificate of Title (SHM) but is not authorized to make an authentic deed of sale and purchase of land with certificate of title (AJB), ${ }^{5}$

With the help of a Notary, the parties make the Sale and Purchase Agreement, formulating the matters to be promised must be in accordance with Article 1338 of the Civil Code. But an agreement can not always work in accordance with the agreement desired by the parties. Under certain conditions can be found various things that can lead to such an agreement undergoing cancellation, either revoked by the parties or by court order. ${ }^{6}$

In the PPJB conducted, the parties agreed to bind themselves to each other. Prospective seller is bound to sell the rights to the land to the prospective buyer with the conditions including the object, price, method of payment, power given to the buyer, the responsibilities of the heirs of the parties and other promises, With the agreement, the buyer to resolve the matter after they reach an agreement on what is being sold and at what price to pay.

Provided that it provides legal protection to the parties in the PPJB act on the promise to give power from the prospective seller to the prospective buyer. This power is given only so that the prospective buyer is protected in implementing the PPJB without involving the prospective seller to perform AJB. The provisions or promises concerning the agreement also do not end because one of the parties died, but are hereditary and must be fulfilled by their respective heirs. Based on these provisions, the heirs of the parties will later replace the rights and obligations of the deceased.

PPJB is a legal act that precedes the process of transfer of rights to land as a form of alliance, PPJB land contains the rights and obligations of the parties who made it, so that if the things that have been agreed in the deed of sale is violated or not met by the the party who made it then the parties are the ones who have the authority to request the cancellation of the agreement in court. In practice, the sale and purchase

\footnotetext{
${ }^{4}$ Setiawan Rahmat, Principles of Alliance Law, Putra Abardin, Bandung, $2005 \mathrm{p}$.

${ }^{5}$ Ramdan, Harijanto, Obligations in the Implementation of the Sale and Purchase of Certified Land, Pustaka Ilmu, Jakarta 2010 p. 36

${ }^{6}$ Lina Haryanti Latif | The Legal Strength of the Sale and Purchase Agreement (PPJB) on Land and Buildings Between Buyers and Developers is Associated with the Implementation of Pilot Decisions Against Developers. Thesis. Jogjakata: Gadjah Mada University. 2014. Hal. 6-7
} 
agreement can be revoked by the heirs. It is interesting to study further considering the sale and purchase agreement made by the heirs but requested cancellation by the heirs.

This is not in accordance with the principles of western heir law and Islamic heir law, where in western heir law / KUHPerdata there is a principle that "when a person dies, then immediately all his rights and obligations turn to all his heirs". These rights and obligations as long as they are included in the field of property law or only rights and obligations that can be assessed with money set out in Article 830 of the Criminal Code that is, inheritance only takes place due to death, while Inheritance Law according to the Compilation of Islamic Law adheres to one of the bilateral principles, that is, a person receives the right of inheritance from both sides of the lineage, namely from the female lineage as well as the male lineage. This principle is strictly stated in the QS. an-Nisa verses: 7, 11, 12, and 176.

Thus in the estate of a deceased person, arrangements are made for the transfer of the property he left behind, as well as the consequences for the heirs. This means that both the assets and passions of the heirs' obligation to carry out what the heirs left behind because after the heirs die, then immediately the rights and obligations shift to the heirs based on the principle of le mort saisit le vif which means the deceased adheres to people who are still alive. ${ }^{7}$

\section{Research Methods}

The method of approach used in this study is the sociological juridical approach. The sociological juridical approach is an approach based on the main legal material by studying the theories, concepts, principles of law and legislation related to this research.

\section{Result and Discussion}

3.1. The Legal Position of the Heirs in the Case of the Sale and Purchase Agreement entered into by the Heir

All living things are impossible without process, one of which is birth. Along with the birth, other life developments take place, meaning that everything covered in life passes through the space of birth, whether it is a plant, an animal that is clearly different, especially with humans. That difference makes man aware of himself, so that awareness raises basic questions for himself that he should answer and face as a living-conscious being. With the questions and answers presented through his consciousness clearly and healthily to get a meeting in the fundamentals of the belief of belief that by knowing the causes and cycles that also present the belief in the existence of the creator, give birth to all these things (universe) ${ }^{8}$

\footnotetext{
${ }^{7}$ R. Soetojo Prawirohamidjojo. Coding Inheritance Law. Airlangga University Press, Jakarta 1998. Hal. 6

${ }^{8}$ Mohsen Gharawiyan, 2012, Dar Amadi bar Amuzesye Falsafe. Terj, M. Nur Djabir, Introduction to Understanding the Basic Book of Islamic Philosophy: An Explanation for Approaching the Theoretical Analysis of Islamic Philosophy Sadra Press, Jakarta, p. 2-3.
} 
According to Van Apeldoorn, a legal event is an event based on the law of giving up or abolishing rights. In a simpler sense, legal events or legal events or rechtsfeit are social events that are consequently regulated by law. This legal event is an event in society that moves a certain rule of law so that the provisions listed in it are then realized. In more detail we can say as follows: if in an event an event arises, while the event is in accordance with what is described in the rules of law, then the rules are then applied to the event. ${ }^{9}$ The legal consequences that subsequently arise, with the occurrence of a person's legal event include the problem of how to manage and continue the rights and obligations of a person who dies. ${ }^{10}$ The settlement of rights and obligations as a result of the death of a person is regulated by inheritance law.

Inheritance is the essence of causality (the main cause) in owning property, while property is the lining of life, both individually and universally. With this treasure, the soul of life always revolves. ${ }^{11}$ Inheritance law is a law that regulates the transfer of assets left by a person who dies and the consequences for his heirs. In principle, only the rights and obligations in the legal field of property / property can be inherited. ${ }^{12}$

Islamic law also stipulates the right of transfer of ownership of a person after death to his heirs, from all his relatives and lineage, without distinction between men and women, large or small. The Qur'an explains and details in detail the laws related to inheritance rights without neglecting anyone's rights. The part that must be accepted is all explained in accordance with the position of the lineage to the heirs. In the letter of An-Nissa verse 7 which means:

"For men there is a right of inheritance from the parents and relatives and for women there is a right (also) from the property of the parents and relatives either a little or a lot according to the part that has been set".

Based on Act No. 50 of 2009 on changes to Act No. 7/1989 on religious justice, the law of Islamic inheritance is a positive law in Indonesia, especially for Muslims. In its development, the law of inheritance in $\mathrm{KHI}$ is regulated in articles 171 to 193 . The heirs who receive the inheritance from the heirs are not only entitled to their activities but also have the obligation to receive their passions, namely the debts of the heirs. Not all heirs' rights and obligations can be transferred to the heirs. Inherited property often causes problems in the family. There are many risks that arise in relation to this heritage property. If it is not wise to treat it, conflicts in the family can happen and result in strains and even break the family ties.

The heirs can cancel the sale and purchase of the heirs' land if the legal conditions of the sale and purchase are not met through the court. Heirs who do not give their

\footnotetext{
${ }^{9}$ Satjipto Rahardjo, 2012, Legal Science, Citra Aditya Bakti, Bandung, p. 35

10 Eman Suparman, 2007, Indonesian Inheritance Law, Refika Aditama, Bandung, p. 27

11 Muhammad Ali as-Shabuni, 1995, Inheritance Law in Islamic Syari'at, CV.Diponogoro, Bandung, Cet.

III, pp. 39 and 40

${ }^{12}$ Effendi Warsin, Inheritance Law, (Jakarta: PT. Raja Grafindo Persada, 2008), p
} 
consent in the sale and purchase of inherited land as their right, have the right to cancel the sale and purchase of the land. If an agreement does not meet the subjective requirements, then the agreement can be canceled. An agreement that does not meet the objective requirements then the agreement is void for the sake of law. Can be canceled here means that one of the parties can request cancellation, but the agreement itself remains binding on both parties as long as it is not canceled (by the judge) at the request of the party entitled to request the cancellation earlier (nonspeaking party or party who freely agrees). Cancel for the sake of law is from the beginning considered never an agreement was born and never an alliance. Buying and selling is considered to have occurred when the parties have reached an agreement on the property and its price, even though the property has not been submitted. Land buying and selling is a process of transfer of rights by using the basic principles of Light and Cash. It is clear that the sale and purchase must be done in the presence of authorized public officials, authorized public officials such as the Head of Customs, Sub-District Head, and PPAT. Cash means the sale and purchase price must be paid in cash. Land buying and selling is a process of transfer of rights by using the basic principles of Light and Cash. It is clear that the sale and purchase must be done in the presence of authorized public officials, authorized public officials such as the Head of Customs, Sub-District Head, and PPAT. Cash means the sale and purchase price must be paid in cash. Land buying and selling is a process of transfer of rights by using the basic principles of Light and Cash. It is clear that the sale and purchase must be done in the presence of authorized public officials, authorized public officials such as the Head of Customs, Sub-District Head, and PPAT. Cash means the sale and purchase price must be paid in cash. ${ }^{13}$

The issue of heirs is still a cause of conflict in society, this is possible because they do not yet understand the heirs in depth. Sometimes the problem of heirs is seen as less important in the rules of science, considering that the problem is considered as something that is normal in life in court. ${ }^{14}$

From the point of view of sale and purchase, can be defined the meaning of sale and purchase is an agreement with which one party binds himself to hand over ownership of an item and the other party to pay the promised price. ${ }^{15}$ The one promised by one party (seller), surrenders or transfers his property on the goods offered, while the one promised by the other party, pays the price he has agreed. Although it is not mentioned in any of the articles in the legislation, it is certain that this price must be a sum of money, because if it is not so and the price is in the form of goods, then it is no longer a sale or purchase, but an exchange or barter.

What the seller has to hand over to the buyer is the ownership of the goods, so it is not just the power over the goods. All that needs to be done is to submit or "levering"

\footnotetext{
${ }^{13}$ Irma Devita Purnamasari, 2010, Smart, Easy, And Wise Tips to Overcome Land Law Problems, Kaifa, Bandung, p. 16

${ }^{14}$ Zainuddin Ali, Implementation of Inheritance Law in Indonesia, Ctk. Second, Jakarta: Sinar Grafika, 2010, p. 15

${ }^{15}$ Subject, Law of Agreement, Intermasa, Jakarta, 2004, p. 79.
} 
juridically. Sale and purchase is a consensual agreement, meaning it has been born as a valid agreement (binding or has the force of law) at the moment of agreement reached between the seller and the buyer on the basic elements of goods and prices, even if the sale and purchase is about goods that are not moving. The consensual nature of this sale and purchase is emphasized in Article 1458 which reads, "Sale and purchase is considered to have occurred between the two parties when they have reached an agreement on the goods and prices, although the goods have not been delivered or the price has not been paid".

\subsection{Legal Protection To Buyers In The Case Of A Sale And Purchase Agreement Is Canceled By The Heirs}

In the sale and purchase of course can not always go well, sometimes things arise that are actually unexpected from the parties, one example in this case one of the heirs hinders the implementation of the sale and purchase deed. In this case it can be said that the heirs referred to as the seller to sue the heirs have made a wanprestasi.

PPJB in practice is possible to be canceled unilaterally by one party or by agreement of both parties. In addition, PPJB can also be revoked by a court decision. PPJB right over land that has been made by the parties can be revoked if one of the parties does not perform what is his obligation.

Based on Article 13 of the Ministerial Regulation of PUPR Number 11 / PRT / M / 2019 on the PPJB Rumah System, namely:

a. In the event of cancellation of the purchase of the House after the signing of PPJB due to the negligence of the construction actors then all payments received must be returned to the buyer.

b. In case of cancellation of the purchase of the House after the signing of PPJB due to the negligence of the buyer then:

"If the payment has been made by the buyer at a maximum of $10 \%$ (ten percent) of the transaction price, the entire payment becomes the right of the developer; or if the payment has been made by the buyer more than $10 \%$ (ten percent) of the transaction price, the developer is entitled to deduct $10 \%$ (ten percent) of the transaction price ".

PPJB includes the type of advance agreement from the main agreement, namely the sale and purchase act which must be made before the Land Act Making Office (PPAT). According to Herlien Budiono, a preliminary agreement is an agreement in which the reason for the preliminary agreement depends entirely on another agreement, while the basic agreement is an agreement that has a reason (independent) for the existence of the agreement. In the advance agreement there are promises that have been agreed by both parties to bind each other. In this case, that the PPJB has been made in the form of an authentic deed made before a Notary, in the sense that the PPJB act has strong legal force in evidence in court. 
This Act has been signed by the seller and the buyer with the payment term 4 (four) times. The seller has 3 (three) heirs. The buyer has fulfilled his achievement in this PPJB by making payment on the land 4 (four) times and has paid for it.

In other words, that the buyer has fulfilled his achievement, that the achievement in an agreement must be implemented by the parties. In accordance with the provisions of Article 1234 of the Civil Code which states that every alliance is to give something, to do something, or not to do something. The buyer in this case has the right to request fulfillment from the seller. The achievement that must be done by the seller is to implement the transfer of ownership by making a deed of sale and purchase that will be made in front of PPAT because in PPJB it has been promised that if payment is completed for 4 (four) terms and pay then the seller must make a deed of sale in front of PPAT.

However, there are constraints during the process of the agreement of both parties, the seller dies when the buyer has completed his performance. In this case, that inheritance property is regulated in Book II of the Criminal Code. These provisions are set out in Article $\mathbf{5 8 4}$ of the Criminal Code which states that inheritance is one of the limited means of obtaining property rights, as well as objects from the inheritance as a fundamental element of property ownership. The buyer is protected in the event of a claim, as his or her performance has been met. Meanwhile, in Article 1381 of the Criminal Code, one of the cancellations of the agreement is due to payment. The buyer has paid in full the price of the land that has been promised in PPJB.

With reference to Article 1243 of the Civil Code which explains the substitution of costs, losses and interest does not contain a word, then it becomes obligatory, if the debtor, after being declared negligent to fulfill the alliance, still neglects it, or if what should be given or made, can only be given or made in spare time that has been exceeded.

So important is the good faith that in negotiations or agreements between the parties, both parties will face in a legal relationship, especially good faith. Every party who makes and implements an agreement must abide by it in good faith. Article 1338 paragraph (3) of the Criminal Code states that all agreements must be executed in good faith, meaning that in the act and implementation of the agreement must respect the substance of the agreement based on the firm belief or belief or goodwill of the parties.

As already explained above, that the heirs have an obligation to implement the agreement that has been made by the heirs with the buyer. The heirs must implement the deed of sale and purchase which will be made in front of PPAT in accordance with the promise made by the heirs with the buyer in PPJB. Legal protection on the part of the buyer is that the buyer has the power of proof of the PPJB act made by a Notary before the court. The buyer can file a claim for the heirs to implement the sale and purchase act. The buyer here has been harmed by the presence of one of the heirs who refused to implement the sale and purchase act. Because the land is still jointly owned by the heirs as a whole. 


\subsection{Responsibilities and Consequences of the Law of Cancellation of Unilateral Bonding Agreement}

According to the law of responsibility is a consequence of the consequences of a person's freedom of conduct related to ethics or morals in performing an act. Furthermore, responsibility must have a basis, which is what causes the emergence of legal rights for a person to sue others as well as things that give birth to the legal obligation of others to give responsibility. In general, the principle of responsibility in law can be distinguished as follows: ${ }^{16}$

\section{Principle of liability based on fault}

This principle is a fairly common principle applicable to civil law, especially Articles 1365, 1366, and 1367 of the Civil Code. In general, this principle of responsibility is acceptable because it is fair to the wrongdoer to make up for the loss on behalf of the victim. In other words, it is not fair if the innocent should compensate for the losses suffered by others. ${ }^{17}$

What needs to be clarified in this principle is the definition of the subject of the offender whose legal doctrine is known as the basis of vicarious liability and corporate liability. Vicarious liability means that the company is responsible for the losses of other parties caused by the person or employee under its control. Corporate liability has the same meaning as vicarious liability. According to this doctrine, the institution that oversees a group of workers has a responsibility to the workforce it employs.

According to civil law, accountability is divided into two types, namely mistakes and risks. Thus it is known as liability without fault (liability without based on fault) and liability without fault (liability without fault) which is known as risk liability or strict liability. ${ }^{18}$

Based on the law of the alliance, the responsibilities are differentiated, namely: (a) legal responsibilities due to the agreement / contractual relationship (privity of contract) as stated in Article 1338 and Article 1317 of the Civil Code. (b) legal liability. Responsibility based on contractual relations, arises when there is a performance or violation of the agreement, while liability under the law is a liability based on acts against the law.

In this case, that the seller is initially done by the heir, then there must be a transfer of obligations from the heir to the PPJB. It has been explained before, that the obligations and rights of the heirs directly transfer and are the responsibility of the heirs. However, in this case, one of the heirs did not agree to implement the deed of sale, on the grounds that he was not included in the PPJB conducted by his parents. Looking at the provisions of Article 1318 of the Criminal Code that the heirs should still implement the deed of sale and purchase.

\footnotetext{
${ }^{16}$ Celina Tri Siwi Kristiyanti, (2008). "Consumer Protection Law", Jakarta: PT. Graphic Rays, p. 92.

${ }^{17}$ Ibid, p. 93

${ }^{18}$ Ibid, p. 94
} 
Proof in wanprestasi based on agreement, then what must be proved in court are any matters that are violated by the defendant. Therefore, the legal responsibility that must be done by the buyer because he has done wanprestasi that is in accordance with Article 1276 KUHPerdata which essentially (1) meet and execute the loan, (2) fulfill the agreement accompanied by the obligation to pay compensation; (3) pay compensation; (4) cancel the agreement; (5) cancel the agreement accompanied by damages.

In PPJB it has been promised that once the buyer has settled the payment for the land with a payment of 4 terms, then the buyer and the seller will continue the transfer of rights by making a deed of sale made in front of PPAT. Here the buyer has fulfilled his obligations in the agreement, thus the buyer has the right to accept his rights. While the seller has fulfilled his rights, then the seller must fulfill his obligation to transfer those rights. However, the fact is that the seller has died and shifted his obligations to the heirs.

One of the heirs does not agree to the making of the deed of sale and purchase, so that the buyer suffers a loss and has not fulfilled his rights. So the seller has made a wanprestasi. The seller who is the heir has an obligation to continue the agreement, because the heirs receive the obligation from the heirs in general, in the sense that the assets and passions of the heirs are the responsibility of the heirs.

As a result of the law that arises because the seller has made a wanprestasi is the seller must pay compensation that has arisen because the seller prevented the implementation of the deed of sale and purchase. In accordance with the provisions of Article 1234 of the Criminal Code which states that there must be a compensation for loss due to non-fulfillment of an alliance. In this case the seller has not fulfilled the alliance which should have been implemented by the time the buyer has fulfilled his achievement.

The PPJB Deed made by the Notary is basically an authentic act that will not be disputed if one of the parties does not feel harmed, but with the content of the agreement in PPJB containing the things mentioned above, then a dispute may arise because one harmed by the other party. The content of the agreement that is important to be discussed in detail is about the rights and obligations between the seller and the buyer, the price of the object of sale and purchase and payment procedures. The clause can provide legal certainty for the parties after facing the Notary. The formulation of the period in the act is mentioned as to when the buyer will repay with the period already written in the act,

Legal protection in the Sale and Purchase Agreement (PPJB) act can be formulated by the prospective seller, usually in the form of requirements that are usually requested by the prospective seller himself. For example, there are prospective sellers in the Sale and Purchase Agreement (PPJB) which he made asking the buyer to make payment of the buyer with a certain period of time accompanied by conditions of cancellation and sanctions if late payment, there are also those if the buyer does not meet the payment as requested and agreed then the Sale and Purchase Agreement (PPJB) rights 
to the land that has been made and agreed to be void and usually the seller will not take the money that has been paid unless the buyer asks for an exemption.

In contrast to the protection of the prospective seller, protection against the buyer is usually in addition to the requirements also followed by a request for authorization that can not be withdrawn. Sale and Purchase Agreement (PPJB). Additionally other protections are with irrevocable authorization agreements once all the requirements have been met fulfilled to do the sale and purchase, then the buyer can transfer the rights to himself or to others even if the seller is not present in the signing of the Sale and Purchase Act. ${ }^{19}$

Based on the provisions of the applicable law as set out in Article 1320 of the Criminal Code, an agreement is declared valid if it has met four conditions, namely:

1) Those who bound him agreed;

2) Ability to act to make an agreement;

3) The presence of a particular object or thing; and

4) A halal reason

The first two conditions are called subjective conditions, because of the people or subjects who make the agreement, while the last two conditions are called objective conditions because of the agreement itself or the object of the legal act. There are legal implications if one of the conditions is not met. In this case if the objective conditions are not met, the agreement is void for the sake of the law. It means that an agreement was never born and there was never an alliance. Thus, there is no basis for the parties to sue each other in court (null and void). Regarding subjective conditions, if the conditions are not met then the agreement is not void for the sake of law, but one of the parties has the right to request that the agreement be revoked. ${ }^{20}$

Sale and Purchase Agreement (PPJB) rights to land made by the parties before the Notary can be asked for cancellation if one of the parties feels harmed. Compensation in civil law may arise due to performance as a result of an agreement or may arise due to acts against the law. Compensation that arises from the performance is if there are parties in the agreement who do not fulfill their commitment that has been set out in the agreement, then according to the law he can be held responsible, if the other party in the agreement suffers losses as a result.

If PPJB is asked for cancellation, of course there will be legal consequences to the PPJB act. In addition, what needs to be known is how legal protection is when the buyer who cancels PPJB does the opposite. Such as administrative sanctions. Administrative sanctions are acts of the Government to end a situation that is prohibited by the rules

\footnotetext{
$19 \mathrm{lbid}$

${ }^{20}$ Subekti, Op. it., p. 20.
} 
of administrative law or to do what should be left by the citizens because it is against the law or other rules of law.26

If either the seller in this case is the heir or the buyer chooses to settle a dispute in court, then if the buyer who filed the lawsuit the buyer must as far as possible prove that his opponent has made a wanprestation, not an overmacht. Similarly with the Seller, the seller must convince the judge if the fault does not lie with him in defense such as compelling circumstances, stating that the buyer has relinquished his rights, and the negligence of the buyer.About the negligence or negligence of the debtor (the debtor or the buyer as the obligatory party) ), threatened with some sanctions or punishment. There are four types of penalties or consequences received by the negligent debtor, namely:

1) Paying for losses suffered by creditors or in short is called damages.

2) Cancellation of an agreement or also called a breach of agreement.

3) Risk transition.

4) Pay the cost of the case, if it is settled before a judge.

In relation to the stated party must pay a fine due to the cancellation of the PPJB, then the elements as mentioned above should be proven first. If the stated party of the performance has met the four elements above, then the party stated the performance is obliged to reimburse the loss. Therefore, in a PPJB should be clearly mentioned about the horrible sanctions if one of the parties is declared wanprestasi. This is to prevent if later there is a dispute between the parties.

\section{Closing}

\subsection{Conclusion}

1. The reason for the cancellation of the Sale and Purchase Agreement (PPJB) can occur either because of the buyer or the heirs. As for the things that can cause the cancellation of PPJB made in the presence of a Notary from the heirs is that the heirs do not do their duty to provide achievements that have been agreed by both parties before the heir dies, so that the heirs do not do their duty as it turns out in the Law, then the buyer will ask for compensation to the heirs. However, if the two parties do not get a solution to the problem, then the affected party can sue the party who caused the loss in court or by canceling the agreement that has been made by the parties. Besides, other causes may come from the heirs who are negligent in carrying out their obligation to hand over ownership of the land that has been agreed in the Sale and Purchase Agreement (PPJB) made before the Notary. The obligations written in the Sale and Purchase Agreement (PPJB) between the two parties must be implemented even if the heir has died, because if not implemented, it can cause problems between the parties. Because the Buyer does not make the payment as promised in the Sale and Purchase Agreement (PPJB), thus the buyer can not be said to have good faith to fulfill his performance, these are 
the things that cause the heirs to feel harmed by the buyer. Since each party feels disadvantaged, The position of the heirs in the sale and purchase agreement made by the heir is only continuing what is promised and can not cancel the agreement, because one of the heirs 'obligations to the heirs is to fulfill the heirs' obligations to third parties and As a good heir of the heirs all that must be done is to fulfill / fulfill the obligation of the heirs in this case to follow up on the land sale and purchase agreement agreement in accordance with the provisions of Article 175 paragraph $1 \mathrm{~b}$ Compilation of Islamic Law so as not to request the cancellation of the land sale and purchase agreement.

2. As a result of the cancellation of the Sale and Purchase Agreement (PPJB) made in front of a Notary due to performance can cause the cancellation of the deed made before the Notary that the Sale and Purchase Agreement (PPJB) can be revoked if it does not meet the subjective elements or void by law if it does not meet the objective elements as in Article 1320 of the Criminal Code which states the terms of the validity of the agreement. In addition to the cancellation of the deed made before the Notary, there are also things that must be paid by the party who made the wanprestasi that is a fine that must be paid by the party who made the act of wanprestasi in this case when the matter is brought before the court.

\subsection{Suggestions}

1. Notary as a public official authorized to make an authentic act must carry out his duties in accordance with applicable laws and regulations. In the case of making an authentic deed, the Notary is expected to formulate in detail the contents of the deed that has been made and explain and read the meaning of the contents of the act, so that it can minimize acts of representation between the parties because all rules contained in the act can be used as preventive authentic deed made by the Notary in the presence of the parties.

2. Prospective buyers who wish to enter into a sale and purchase agreement are expected to understand the contents of the initial agreement made between the prospective buyer and the seller as well as the actSale and Purchase Agreement (PPJB) as a binding agreement between the prospective buyer and seller. Before signing the deed Sale and Purchase Agreement (PPJB)by the parties before the Notary, then the prospective buyer of land rights must ask questions related to what will be promised, if there is something that can not be understood then the prospective buyer can ask the official authorized to make the act, namely the Notary. By doing this, it can be known the sanctions when the seller performs wanprestasi to potential buyers.

\section{References}

[1] Celina Tri Siwi Kristiyanti. (2008). "Consumer Protection Law”. Jakarta: PT. Rays Graphics

[2] Effendi Perangin. (2008). Inheritance Law. Jakarta: PT. Raja Grafindo Persada. 
[3] Eman Suparman. (2007). Indonesian Inheritance Law. Bandung: Refika Aditama.

[4] Irma Devita Purnamasari. (2010). Smart Tips. Easy. And Wisely Overcome Land Law Problems. Bandung: Kaifa.

[5] Lina Haryanti Latif. (2014). The Legal Strength of the Sale and Purchase Agreement (PPJB) on Land and Buildings between Buyers and Developers is Associated with the Implementation of Pilot Decisions against Developers. Jogjakata: Gadjah Mada University.

[6] Mohsen Gharawiyan. (2012). Dar Amadi bar Amuzesye Falsafe. Terj. M. Nur Djabir. Introduction to Understanding the Basic Book of Islamic Philosophy: An Explanation for Approaching the Theory Analysis of Islamic Philosophy. Jakarta: Sadra Press.

[7] Muchlis Patahna. (2009). Notary Problems. Jakarta: Rajawali.

[8] Muhammad Ali as-Shabuni. (1995). Inheritance Law in Islamic Sharia. Bandung: CV.Diponogoro.

[9] R. Soetojo Prawirohamidjojo. (1998). Code of Inheritance Law. Jakarta: Airlangga University Press.

[10] Ramdan. Harijanto. (2010). Obligations in the Implementation of the Sale and Purchase of Certified Land. Jakarta Pustaka IImu.

[11] Satjipto Rahardjo. (2012). Legal Science. Bandung: Citra Aditya Bakti.Bandung.

[12] Setiawan Rahmat. (2005). Principles of Alliance Law. Bandung: Son of Abardin.

[13] Subject. (1996). Law of the Treaty. Jakarta: Intermasa.

[14] --------. (2004). Law of Agreement. Jakarta: Intermasa.

[15] Supriadi. (2006). Ethics and Responsibilities of the Legal Profession in Indonesia.Jakarta: Sinar Grafika.

[16] Zainuddin Ali. (2010). Implementation of Inheritance Law in Indonesia. Ctk. Second. Jakarta: Sinar Graphics.

\section{Regulations:}

[1] Act No. 5 of 1960 on the Basic Rules of Agrarian Trees.

[2] Civil Law Law Book

[3] Compilation of Islamic Law 
[4] Government Regulation No. 37 of 1998 on the Regulations of the Department of the Office of the Deed maker Land (PPAT)

[5] Government Regulation Number 24 of 1997 on Land Registration

[6] Instruction of the Minister of Home Affairs Number 14 of 1982 on ProhibitionUse of Power Absolutely Seas a Transfer of Land Rights

[7] Regulation of the Minister of Public Works and People's Housing Number: 11 / PRT / M / 2019 of 2019 about Home Sale Purchase Agreement System.

[8] Regulation of the Minister of State for Agrarian Affairs No. 3 of 1997 on the provisions of the implementation of Government Regulation Number 24 of 1997 